\title{
FAKTOR PENYEBAB KESULITAN MEMBACA PESERTA DIDIK DI SDN-5 PANARUNG
}

\section{Difficulty Of Cause Of Difficult Reading Students At SDN-5 Panarung}

\author{
Oleh: Hendri
}

hendripily@gmail.com

\begin{abstract}
ABSTRAK
Penelitian ini bertujuan untuk mengetahui faktor-faktor apakah yang menjadi penyebab kesulitan membaca pada peserta didik kelas III di SDN-5 Panarung.

Populasi dalam penelitian ini adalah 31 orang peserta didik kelas III SDN-5 Panarung. Instrumen dalam penelitian ini adalah berupa angket. Metode yang digunakan adalah metode deskriptif kuantitatif dan hasil datanya dianalisis dengan menggunakan rumus persentase.

Berdasarkan hasil penelitian pada peserta didik kelas III SDN-5 Panarung Palangka Raya didapat bahwa faktor dominan yang menjadi penyebab kesulitan peserta didik dalam membaca adalah kurang mengenal huruf 54,04\%, faktor kedua adalah menghilangkan huruf 23,62\%, sedangkan faktor terakhir adalah membaca kata demi kata $22,34 \%$.
\end{abstract}

Kata Kunci : Penyebab Kesulitan Membaca, Peserta Didik

\section{ABSTRACT}

This study aims to determine what factors are the cause of reading difficulties in grade III students in Panarung SDN-5.

The population in this study were 31 students of class III Panarung SDN-5 in the Academic Year 2017/2018. The instrument in this study was a questionnaire. The method used is a quantitative descriptive method and the results of the data are analyzed using the percentage formula.

Based on the results of research on students in grade III SDN-5 Panarung Palangka rayadatapat that the dominant factor that causes students difficulty in reading is not familiar with letters $54.04 \%$, the second factor is eliminating letters $23.62 \%$, while the last factor is reading words for word $22.34 \%$.

Keywords: Causes of Reading Difficulties, Learners

\section{PENDAHULUAN}

Membaca menduduki posisi peran yang sangat penting dalam konteks kehidupan umat manusia, terlebih pada era informasi dan komunikasi sekarang ini. Membaca juga sebuah jembatan bagi siapa saja dan dimana saja yang berkeinginan meraih kemajuan dan kesuksesan, baik di lingkungan dunia pendidikan maupun di dunia pekerjaan.

Membaca adalah kegiatan fisik dan mental yang dapat berkembang menjadi suatu kebiasaan. Disamping itu, dalam usaha pembentukan kebiasaan membaca, dua aspek yang diperlukan diperhatikan, yaitu minat (perpaduan antara keinginan, kemauan, dan motivasi) dan keterampilan membaca.

Membaca berperan sangat penting dalam belajar. Dengan demikian membaca tidak dapat dianggap sebagai subjek yang terpisah dalam studi. Membaca adalah salah satu alat pendidikan yang dipergunakan sejak dari tingkat sekolah dasar sampai sepanjang individu melangsungkan pendidikannya. 
Guru bidang studi perlu membekali diri dengan berbagai kompetensi pengajaran membaca yang relevan jika mereka benar-benar menghendaki peserta didik mencapai prestasi yang diharapkan Syaiful Bahri Djamarah (2002:44). Kemajuan kemampuan membaca pada umumnya memang bergerak teratur, namun keistimewaan-keistimewaan tertentu bisa terjadi pada setiap anak.

Beberapa faktor penyebab rendahnya kemampuan membaca bangsa kita antara lain: pertama, tradisi kelisanan, Kedua, akibat sistem persekolahan yang kurang memberikan peluang yang cukup bagi hadirnya tradisi keberaksaan atau tradisi membaca kepada para peserta didik.

Thorndike, (dalam Kholid A Harras, dkk 1999:25) mengatakan bahwa proses membaca itu tak ubahnya dengan proses ketika seseorang sedang berpikir atau bernalar.Proses membaca tidak terjadi secara berturut-turut dan tidak terjadi secara linier, sehingga meningkatkan keterampilan membaca para peserta didik merupakan hal yang sangat penting; akan tetapi menumbuhkan minat dan kebiasaan membaca jauh lebih penting. Selain itu memperkaya wawasan dan pengalaman peserta didik melalui penugasan membaca itu penting, tetapi menjaga sikap peserta didik dari kejenuhan dan kebosanan akan bahan bacaan juga tidak kalah penting. Membaca menduduki posisi peran yang sangat penting dalam konteks kehidupan manusia, terlebih pada era informasi dan komunikasi seperti sekarang ini, namun kenyataan yang terjadi di SDN-5 Panarung bahwa saat diadakan observasi oleh peneliti di kelas III SDN-5 Panarung, pada saat itu sedang berlangsung proses pembelajaran Bahasa Indonesia ternyata masih ada peserta didik yang mengalami kesulitan membacaberdasarkan data dokumentasi hasil belajar bahasa Indonesia, Dari 31 peserta didik kelas III ada 15 peserta didik yang nilainya 54 atau kurang dari nilai rata-rata, KKM untuk pelajaran Bahasa Indonesia yaitu 60. Salah satu penyebab yang dialami 15 peserta didik tersebut adalah mengalami kesulitan belajar khususnya saat pelajaran membaca. Selain melakukan observasi peneliti juga melakukan wawancara singkat dengan guru kelas mengenai kesulitan membaca pada peserta didik. Hal tersebut disebabkan oleh dua faktor yaitu faktor internal peserta didik yaitu pada saat membaca peserta didik kurang mengenal huruf, membaca kata demi kata, dan menghilangkan huruf. Misalnya dalam kata sabtu dibaca saptu, seseorang dibaca seorang. Sedangkan faktor eksternal peserta didik seperti, keadaan keluarga atau peran orang tua yang kurang perhatian untuk memberikan dorongan dan motivasi sehingga anak dapat belajar dengan tekun. Keadaan sekolah seperti kurangnya interaksi guru dengan peserta didik pada saat proses belajar mengajar. Kesalahan dan kekurangan tersebut dapat menghambat belajar peserta didik.Berdasarkan fenomena tersebut, peneliti tertarik untuk melakukan penelitian tentang faktor-faktor penyebab kesulitan membaca peserta didik di SDN-5 Panarung.

"Membaca adalah suatu proses yang dilakukan atau dipergunakan oleh pembaca untuk memperoleh pesan yang hendak disampaikan oleh penulis melalui media kata-kata/bahasa tulis", Tarigan (dalamDalyono, 2010:62).

Membaca pada hakikatnya adalahsuatu yang rumit yang melibatkan banyak hal, tidak hanya sekedar melafalkan tulisan, tetapi juga melibatkan aktivitas visual, berfikir, psikolinguistik, 
dan metakognitif. Dalam pelaksanaan membaca ini diperlukan keseriusan dan keinginan yang kuat dari diri si pembaca. Tidak jarang sering kita temukan banyak peserta didik yang tidak begitu tertarik dalam membaca. Hal ini disebabkan dikarenakan keinginan yang lemah dari peserta didik itu sendiri. Itulah sebabnya mengapa membaca itu memerlukan keinginan yang kuat dari diri si pembaca untuk melakukan aktivitas membaca.

Dalam kamus besar bahasa Indonesia, "kemampuan" sama dengan dapat melakukan sesuatu, (KBBI, 2007:423). Sedangkan membaca adalah "mengeja" atau melafalkan apa yang tertulis" (KBBI, 2005:83). Sehingga kemampuan membaca dapat diartikan sebagai suatu kemampuan yang dimiliki seseorang untuk mengeja atau melafalkan apa yang tertulis "mengeja" yaitu melafalkan huruf-huruf satu demi satu, (KBBI, 2007:134). Sedangkan "Mengucapkan" sama dengan melafalkan atau melisankan, (KBBI, 2007:804). Departemen Pendidikan Nasional, Direktorat Jenderal Pendidikan Dasar dan Menengah. (2008:31).

Dalam kegiatan membaca terjadi proses pengolahan informasi masukan yang terdiri atas informasi visual dan informasi non visual. Informasi visual merupakan informasi yang dapat diperoleh melalui indera penglihatan, sedangkan informasi non visual merupakan informasi yang sudah ada dalam benak si pembaca. Karena pembaca memiliki pengalaman yang berbeda-beda dan mempergunakan pengalaman itu menafsirkan informasi visual ada dalam teks, makna teks akan berubah-ubah sesuai dengan pengalaman penafsiran.

\section{Faktor-faktor Penyebab Kesulitan Membaca}

\section{Faktor Eksternal}

Salah satu faktor penyebab kesulitan membaca adalah faktor eksternal, faktor eksternal yang dapat menjadi penyebab kesulitan membaca adalah keadaan keluarga dan keadaan sekolah. Slameto (Dalam MulyonoAbdurrahman, 2003:52).

a. Keadaan Keluarga

Sri RahayuHaditono (2006:3) bahwa "Keluarga adalah lembaga pendidikan pertama dan utama". Keluarga yang sehat besar artinya untuk pendidikan kecil, tetapi bersifat menentukan dalam ukuran besar yaitu pendidikan bangsa, negara dan dunia. Adanya rasa aman dalam keluarga sangat penting dalam keberhasilan seseorang dalam belajar. Rasa aman itu membuat seseorang akan terdorong untuk belajar secara aktif, karena rasa aman merupakan salah satu kekuatan pendorong dari luar yang menambah motivasi untuk belajar.

Oleh karena itu orang tua hendaknya menyadari bahwa pendidikan dimulai dari keluarga. Jalan kerjasama yang perlu ditingkatkan, dimana orang tua harus menaruh perhatian yang serius tentang cara belajar anak di rumah. Perhatian orang tua dapat memberikan dorongan dan motivasi sehingga anak dapat belajar dengan tekun. Karena anak memerlukan waktu, tempat dan keadaan yang baik untuk belajar.

b. Keadaan Sekolah

"Peranan guru itulah yang memegang peranan yang terpenting, dalam arti bahwa perhatian guru pribadi terhadap peserta didiknya lebih memajukan perkembangan anak daripada organisasi sekolah, dimana seorang guru lebih sering menghadapi anak-anak dari kelas itu", W.A. Gerungan (dalamM. Asrori, 2007:35). Oleh sebab itu, pendidik harus dituntut untuk menguasai bahan pelajaran yang disajikan, dan memiliki metode yang 
tepat dalam mengajar, interaksi dengan peserta didiknya, serta perhatian terhadap masalah-masalah yang dihadapi peserta didiknya.

Sekolah merupakan lembaga pendidikan formal pertama yang sangat penting dalam menentukan keberhasilan belajar peserta didik, karena itu lingkungan sekolah yang baik dapat mendorong untuk belajar lebih giat lagi. Keadaan sekolah ini meliputi cara penyajian pelajaran, hubungan guru dengan peserta didik, alatalat pelajaran dan kurikulum. Hubungan antara guru dan peserta didik kurang baik akan mempengaruhi hasil-hasil belajarnya.

1. Faktor Internal

Faktor-faktor internal penyebab peserta didik kurang lancar membaca menurut Tarmizi, dalam (Farida Rahim, 2008:46) adalah:

a. Kurang Mengenal Huruf

Kesulitan tidakmampuan peserta didik mengenali huruf-huruf seringkali dijumpai guru. Ketidakmampuan peserta didik membedakan huruf besar dan kecil termasuk dalam kategori kesulitan. Ketidak jelasan peserta didik melafalkan sebuah huruf sering terjadi, khususnya seperti huruf: [b], [c], [d], [p], [v].

Untuk memastikan apakah peserta didik mengalami kesulitan dalam mengenali huruf dapat dilakukan melalui pengujian secara informal atau pengujian secara formal dengan menggunakan tes pengenalan huruf.

b. Menghilangkan Huruf

Penghilangan huruf sering dilakukan oleh peserta didik berkesulitan membaca karena adanya kekurangan dalam mengenal huruf, bunyi bahasa dan bentuk kalimat. Penghilangan huruf biasanya terjadi pada awal kata.

Kesulitan penghilangan ini adalah peserta didik menghilangkan (tidak dibaca) satu huruf, kata dari teks yang dibaca misalnya :Tujuh dibaca tuju, Bapak dibaca bapa, Majalah dibaca majala dan lain-lain.

Penghilangan huruf, ini biasanya dilakukan oleh ketidakmampuan peserta didik mengucapkan huruf-huruf yang membentuk kata. Bahkan ada huruf yang sengaja tidak dibaca karena sulit membacanya.

c. Membaca Kata Demi Kata

Peserta didik yang mengalami kesulitan jenis ini biasanya berhenti setelah membaca sebuah kata, tidak segera diikuti dengan kata berikutnya. Membaca kata demi kata seringkali disebabkan oleh :Gagal memahami makna kata, atauKurang lancar membaca.

Membaca kata demi kata memang merupakan tahap awal dari kegiatan membaca. Akan tetapi jika peserta didik tidak mengalami kemajuan dalam hal tersebut, maka dia termasuk kategori peserta didik yang menghadapi masalah.

\section{METODOLOGI PENELITIAN}

Dalam penelitian ini peneliti menggunakan metode deskriptif kuantitatif, karena penelitian yang berusaha untuk menuturkan pemecahan masalah yang ada sekarang berdasarkan data-data, menganalisis dan menginterprestasi. Penelitian ini dilakukan di SDN - 5 Panarung, Kelurahan Panarung Kecamatan Pahandut Kota Palangka Raya.

Populasi dalam penelitian ini adalah peserta didik kelas III SDN - 5 Panarung yang berjumlah 31 orang. Karena jumlah populasi dalam penelitian ini kurang dari 100, maka seluruh populasi tersebut akan digunakan sebagai sumber pengambilan data, sehingga jenis penelitian ini disebut penelitian populasi. 
Penelitian ini merupakan penelitian deskriptif, hanya memuat satu variabel yaitu faktor penyebab kesulitan membaca.

Dalam penelitian ini peneliti membatasi hanya pada faktor internal yang menjadi penyebab kesulitan membaca pada peserta didik. Indikator variabel untuk faktor internal yang mempengaruhi kesulitan membaca peserta didik adalah sebagai berikut:Kurang mengenal huruf, penghilangan huruf, membaca kata demi kata.

Teknik pengumpulan data yang digunakan dalam penelitian ini adalahAngket. Angket yang digunakan dalam penelitian ini adalah angket tertutup yang berupa pilihan ganda, yang terdiri dari item pertanyaan. Adapun kriteria penelitian yang digunakan dalam angket ini adalah dengan skala Gutman yang juga disebut skala Scalorgam yaitu skala yang digunakan untuk jawaban yang bersifat jelas dan konsisten terhadap suatu permasalahan yang ditanyakan, seperti : jawaban nilai

- Ya

- Tidak

Teknik analisis data yang digunakan dalam penelitian ini adalah teknik analisis persentase.

Setelah data terkumpul, kemudian data diolah secara sederhana dengan menggunakan tabel-tabel frekuensi. Kemudian diambil persentase dari hasil tes. Adapun rumus analisis persentase yang digunakan adalah:

- $\mathrm{P}=\frac{F}{N} \times 100 \%$

- Keterangan :

- $\mathrm{P} \quad=$ Persentase

- $\mathrm{F}=$ Frekuensi

- $\mathrm{N} \quad=$ Jumlah
- $100 \%=$ Pengali tetap $($ Anas Sudijono, 2008:43)

\section{HASIL DAN PEMBAHASAN}

Berdasarkan data di atas bahwa dapat direkap faktor penyebab yang paling dominan tiap-tiap faktor adalah sebagai berikut:

Tabel 3

Rekap Faktor Penyebab Kesulitan Membaca Peserta Didik

\begin{tabular}{|l|l|l|}
\hline No & Indikator & Persentase \\
\hline 1. & Kurang mengenal huruf & $54,04 \%$ \\
\hline 2. & Menghilangkan huruf & $23,62 \%$ \\
\hline 3. & Membaca kata demi kata & $22,34 \%$ \\
\hline & Total & $100 \%$ \\
\hline
\end{tabular}

\section{KESIMPULAN}

Berdasarkan hasil penelitian pada peserta didik kelas III SDN-5 Panarung Palangka Raya didapat bahwa faktor dominan yang menjadi penyebab kesulitan peserta didik dalam membaca adalah kurang mengenal huruf $54,04 \%$, faktor kedua adalah menghilangkan huruf $23,62 \%$, sedangkan faktor terakhir adalah membaca kata demi kata 22,34\%. Hal ini menunjukkan bahwa. Kemampuan mengenal huruf adalah kemampuan dasar yang harus dimiliki peserta didik saat mereka membaca. Ketika sudah mengenal huruf maka akan mempermudah untuk melatih kelancaran membaca peserta didik.

\section{DAFTAR PUSTAKA}

Cholid Narbuko dan Abu Achmadi. 2007. Metodologi Penelitian, Jakarta : PT. Bumi Aksara.

Arikunto, Suharsimi. 2006. Prosedur Penelitian, dalam; Suatu Pendekatan Praktek. Jakarta : PT. Rineka Cipta. 
Departemen Pendidikan Nasional, Direktorat Jenderal Pendidikan Dasar dan Menengah, Direktorat Tenaga Kependidikan, (2008), dalam; Membaca.

Djamarah, Syaiful Bahri. 2002. Psikologi Belajar. Jakarta : Rineka Cipta.

Farida, Rahim. 2008. Pengajaran Membaca di Sekolah Dasar, Jakarta: Bumi Aksara.

Haditono, SitiRahayu. 2006. Psikologi Perkembangan. Jogjakarta: Gajah Mada University Press.

M. Asrori. 2007. Psikologi Pembelajaran, Bandung: Penerbit CV. Wacana Prima.

M. Dalyono. 2010. Psikologi Pendidikan, Jakarta : Rineka Cipta.

Muhibin, Syah. 2004. Psikologi Pendidikan dengan Pendekatan Baru. Bandung: PT. Remaja Rosdakarya.

Mulyono, Abdurrahman. 2003. Pendidikan Bagi Anak Berkesulitan Belajar, Jakarta : Penerbit Rineka Cipta.

Santoso, Puji, dkk. 2008. Materi dan Pembelajaran Bahasa Indonesia Sekolah Dasar. Jakarta : Universitas Terbuka.

Saripudin, Udin. 2007. Teori Belajar dan Pembelajaran. Jakarta : Universitas Terbuka.

Sudjana, Nana dan Ibrahim. 2001. Penelitian dan Penilaian Pendidikan. Bandung : Sinar Baru Algensindo.

Sugiyono. 2010. Metode Penelitian Kuantitatif Kualitatif dan $R$ dan $D$, Bandung; Penerbit Alfabeta.

Tim. 2001. Kamus Besar Bahasa Indonesia, Jakarta: Balai Pustaka.
Tim. 2008. Buku Pedoman Penulisan Skripsi. Palangka Raya:Universitas Muhammadiyah Palangkaraya. 